\title{
Relationship between Tax Policy, Growth of SMEs and the Nigerian Economy
}

\author{
Ojochogwu Winnie Atawodi ${ }^{1} \&$ Stephen Aanu Ojeka ${ }^{1}$ \\ ${ }^{1}$ Department of Accounting, Covenant University, Ota, Nigeria \\ Correspondence: Ojochogwu Winnie Atawodi, No. 74 Area F Dodo Mustapha Ring, Ahmadu Bello University, \\ Zaria, Nigeria. Tel: 234-813-901-8298. E-mail: chogwuwin@yahoo.com
}

Received: December 30, 2011

Accepted: June 13, 2012

Published: July 1, 2012

doi:10.5539/ijbm.v7n13p125

URL: http://dx.doi.org/10.5539/ijbm.v7n13p125

\begin{abstract}
This research work tries to establish if any relationship exists between the growth of SMEs and the tax policy environment within which they operate. Using business sustenance and expansion as indices of growth, it analyzes responses obtained questionnaires distributed to SMEs in Zaria, North Central Nigeria. Sampling for the survey was done using the non-probability sampling method specifically by judgmental sampling. The hypothesis was tested using Spearman's Rank Correlation. Although there is a general perception that that tax is an important source of fund for development of the economy and provision of social services, the study revealed a significant negative relationship between taxes and the business' ability to sustain itself and to expand. In order to obtain a vibrant and flourishing SME sector, the tax policy needs to be appropriate such that it will not be an encumbrance to the growth of small and medium enterprises.
\end{abstract}

Keywords: tax policy, SMEs, Nigerian economy

\section{Introduction}

Small and medium enterprises (SMEs) form the core of majority of the world's economies. A study carried out by the Federal Office of Statistics shows that in Nigeria, small and medium enterprises make up $97 \%$ of the economy (Ariyo, 2005). Although smaller in size, they are the most important enterprises in the economy due to the fact that when all their individual effects are aggregated, they surpass that of the larger companies. The social and economic advantages of small and medium enterprises cannot be overstated. Panitchpakdi (2006) sees SMEs as a source of employment, competition, economic dynamism, and innovation which stimulate the entrepreneurial spirit and the diffusion of skills. Because they enjoy a wider geographical presence than big companies, SMEs also contribute to better income distribution.

Over the years, small and medium enterprises have been an avenue for job creation and the empowerment of Nigeria's citizens providing about $50 \%$ of all jobs in Nigeria and also for local capital formation. Being highly innovative, they lead to the utilization of our natural resources which in turn translates to increasing the country's wealth through higher productivity. Small and medium scale enterprises have undoubtedly improved the standard of living of so many people especially those in the rural areas. However, the mortality rate of these small firms is very high. According to the Small and Medium Enterprises Development Agency of Nigeria (SMEDAN) Nigeria, $80 \%$ of SMES die before their $5^{\text {th }}$ anniversary. Among the factors responsible for these untimely close-ups are tax-related issues ranging from multiple taxation to enormous tax burdens.

In many government policies, small and medium enterprises are usually viewed and treated in the same light as large corporations. However, their size and nature makes them unique. Therefore, in dealing with small and medium enterprises, these unique qualities need to be considered. In levying of taxes for these enterprises in particular, issues that need to be considered are how these tax policies can be designed to bolster the growth of SMEs and the most effective ways to administer them. The importance of SMEs as a mechanism of economic growth and development is often ignored. They are perceived as minute establishments that have minimal effect on the state of the economy. However, if a thriving environment is created for these SMEs to grow through proper regulation, the SME sector has the highest propensity to transform developing economies.

In the same light, taxes are important for the government as they are the major source of funds for government 
expenditure. Income obtained from taxation of individuals and businesses are used to run governments as well as provide infrastructure such as good roads, water supply, and electricity which are essential for the smooth running of these businesses that are mainly manufacturing companies and as such rely on these commodities to survive. According to Holban (2007), taxation can contribute to development and to welfare through three sources; It must be able to generate sufficient funds for financing public services and social transfers at a high level of quality, it should offer incentive for more employment and for an efficient and lasting use of natural resources, finally it should be able to reallocate income. In the case of small and medium enterprises, it must at the same time be done in such a manner that puts their income and need for survival into consideration.

The focus of this research therefore is to evaluate tax policies and growth of SMEs in Nigeria, the suitability of tax policies for growth of SMEs, and establish how tax policies affect the Nigerian economy.

\section{Literature Review}

Over the years, Nigeria has depended on oil for its major income and foreign exchange. Oil accounts for about 80 percent of federal government revenues, and 95 percent of foreign exchange earnings. The National Centre for Economic Management and Administration (NCEMA) reports that Nigeria, with a population of about 120 million, is Africa's most populous country and the continent's third largest economy yet it still remains one of the poorest oil producing countries. With a continuously declining per capita income, comparatively unfavorable social indicators, dynamic world economy and the fact that countries are looking into alternative sources of energy it is time to begin to look into alternative sources of income for sustenance in the long run when the demand for oil will dwindle to nothing. Even with the present rates of petroleum products, Nigeria's GDP is below ideal with the SMEs contributing therefore it would not hurt to diversify the economy even before the demand for petroleum products finally diminishes. This means it is time to begin to give more attention to the other sectors of the economy.

This translates into looking at non-oil based sectors in Nigeria such as agriculture, manufacturing, commerce and tourism. These industries are primarily made up of SMEs as such it goes without saying that SMEs are important to the Nigerian economy. The country is blessed with fertile farmlands, vast mineral deposits and a wealth of human resource, making it a very favorable place for small and medium enterprises. These resources have placed Nigeria in a prominent position in Africa. For governments, however, large companies are a more attractive, more clear-cut and less complex set than SMEs. In designing public policies, particularly tax policies, governments have usually targeted their strategies to large companies (Holban, 2007). Therefore, there is a need to devise methods to encourage the growth and development of these enterprises so as to ensure that they reach their full potential. Subsequently, a favorable business and regulatory environment needs to be created for them to thrive. Thus, for this study, the focus will be on supporting SMEs growth through tax policy.

Most large companies have their roots in small and medium enterprises; they started out as SMEs before expanding. This means that the future large corporations are the SMEs today that should be nurtured to ensure their growth. Furthermore, they are generally perceived to be the seedbed for indigenous entrepreneurship and generate all the many small investments, which would otherwise not have taken place (Aryeetey \& Ahene, 2004). Therefore, Nigeria needs to further the development of its private sector by creating an environment favorable to the growth of SMEs, strengthening the factors that lead to business success, and addressing the problems threatening the existence and advancement of small and medium enterprises (Chu, Kara \& Benzing, 2008)

With the dismantling of trade and other barriers, the world has been transformed into a global village. Consequently, SMEs in developing countries are struggling to survive under intense competitive environments both domestic and international. In developing countries like Nigeria, there is an urgent need to provide the required enabling environment for the development of SMEs, so that they could adequately play the role expected of them in economic transformation. Such role includes mobilization of domestic savings for investment, appreciable contribution to gross domestic product, increased harnessing of local raw materials, employment generation, and significant contribution of poverty reduction efforts through sustainable livelihoods and enhancement in personnel income, technological development and export diversification (Smatrakalev, 2006). It is for this reason that an ideal tax policy needs to be adopted in order to ensure economic growth and proper utilization of resources. However this is not the case because taxes which are levied for regulating the investment behavior of the households and not for suffocating any entrepreneur initiative seem to be a major constraint to the development of the SMEs they are out to cater for. 


\subsection{Definition of Terms}

\subsubsection{Small and Medium Scale Enterprises (SMEs)}

The Monetary Policy Circular No. 22 of 1988 of the Central Bank of Nigeria defined small-scale enterprises as enterprises whose annual turnover was not more than $\$ 500$, 000. In the 1990 budget, the Federal Government of Nigeria defined small-scale enterprises for purposes of commercial bank loans as those with an annual turnover not exceeding $\$ 500,000$, and for Merchant Bank Loans, those enterprises with capital investments not exceeding 2 million naira (excluding cost of land) or a maximum of 5 million. The National Economic Reconstruction Fund (NERFUND) put the ceiling for small-scale industries at $\$ 10$ million. Section $37 \mathrm{~b}(2)$ of the Companies and Allied Matters Decree of 1990 defines a small company as one with an annual turnover of not more than 2 million and net asset value of not more than 1 million naira. (Ekpenyong \& Nyong, 1992). The Small and Medium Enterprise Equity Investment Scheme (SMEEIS) sees the SME as "any enterprise with a maximum asset base of $\$ 500$ million (excluding land and working capital), and with no lower or upper limit of staff".

In 1992, the National Council on Industry for the purposes of clarity as regards the definition of SMEs in Nigeria came up with a definition which was to be reviewed every four years, in essence taking care of the lack of uniformity that arose due to the many different definitions as suited the many different bodies making them. This definition divided the small and medium enterprise sector into micro, small and medium enterprises. These sub-categories were defined by the National Council on Industry at their 13th Council meeting. However for tax purposes, Section 40(6) of the Companies Income Tax Act Cap C21 LFN 2004 alludes to companies with a turnover of $\mathrm{N} 1$ million and below operating in the manufacturing, agricultural production, solid mineral mining, and export trade sectors as SMEs; While subsection 8 states that as from 1988 all companies engaged in trade or business with a turnover of N500,000.00 and below qualify as small and medium enterprises. (Iwuji, n.d)

\subsubsection{Characteristics of Small and Medium Enterprises in Nigeria}

The concept of SMEs is relative and dynamic (Olorunshola, 2003). SMEs are characterized by uncertainty, innovation and evolution. A firm understanding of SMEs would require a good knowledge of its features. Aderemi (2003) noted that the SMEs in Nigeria are usually small, owner or family managed business offering basic goods and services, which tend to lack organizational and management structures with the urban ones tending to be more structural than their rural counterparts. This is one of the most generic features of SMEs in Nigeria.

Udechukwu (2003) stated that they are mostly sole proprietorships or partnerships, although on the surface, they may be registered as Limited Liability, while Olorunshola (2003) suggested that this ownership style has led small and medium enterprises to have a simple management structure. Factors also contributing to the reasons small and medium enterprises have a simple management structure are few number of employees and the owners' low level of education. Since there is no legal personality between the small and medium enterprise and its owners, it means the lifespan of the enterprise is dependent on the lifespan of its owners i.e. there is no perpetual continuity.

Furthermore, the production processes of SMEs are usually labour intensive and they usually serve as suppliers for the larger manufacturing firms with their operations being highly dependent on raw materials sourced locally (Hanefah, Ariff, \& Kasipillai, 2002). They also require a lower startup capital than the larger companies (Akinsulire, 2010). While the decisions of the managers have a higher tendency to be subjective given that they are managed and controlled by the same individual. Also, the employee-employer relationship found in most SMEs is predominantly informal.

Another key feature of the SME sector in most countries is that it is heterogeneous, varying in size from small retail outlets to highly paid professionals, and substantial manufacturing enterprises. SMEs are also likely to vary in organizational form from sole proprietorships (with or without employees), small corporations (public or private), professionals and partnerships. This feature usually results in different obligations for record keeping for the enterprise.

In addition, the contribution SMEs usually make to tax revenue is lower than its contributions to output and employment (International Tax Dialogue, 2007). That fact notwithstanding, SMEs have not become competitive enough to increase their share of output even though they form three-fifths of the number of manufacturing firms where larger manufacturing companies rely on SMEs for their supplies. (Hanefah et. al, 2002).

\subsubsection{Challenges Faced by SMEs}

There are several problems that bedevil SMEs and stunt their growth. Though some of these problems are peculiar to a particular country, the challenges faced by SMEs in different countries and geopolitical divisions 
are basically the same. For instance, a survey of Turkish SMEs by Organization for Economic Co-operation and Development (OECD) in 2004 showed that they were suffering the consequences of policy inconsistency, poor access to finance, insufficient know-how and low level of technology, and so many others. Similar problems were reported for other regions like the Philippines, Malaysia, European states and the Sub-Saharan Africa, including, Nigeria. (Aderemi, 2003) (Jan, n.d.). Uzor (2004) suggested that the constraints faced by SMEs in developing countries are not only accentuated with ineffective policy design, but also by market failures in the region.

In addition, Areetey \& Ahene, (2004) listed lack of access to land, utility installation and services, and import procedures as constraints to SME growth. In addition, lack of protection for property rights, which in turn limit SME access to foreign technologies and lack of capacity which affects the enterprise's ability to handle problems of bureaucracy and other such complexities. Other factors are high inflation, and high import dependency, high debt burden on the nation, lack of access to technology, and best of breed business solutions, business services, consulting and training make for an unstable macro-economic environment.

Other problems are astronomically high operating costs; lack of transparency and corruption; and the lack of interest and lasting support for the SMEs sector by government authorities, (Oboh 2002; Okpara 2000; Wale-Awe 2000). Nigerian entrepreneurs cite unreliable employees. Weak economy, unsafe location, undependable electricity supply and lack of management training are closely ranked behind (Chu, Kara \& Benzing, 2008). In addition, because many SMEs produce non-standardized products and due to their lack of awareness of markets skills, they also have problems marketing these products. Yoabin, (2007) maintained that the asymmetry of financing information, high risk of investment and business operation.

\subsubsection{Economic Advantages of Small and Medium Enterprises}

SMEs have been an important tool of economic development for Nigeria. The future of any growing economy such as Nigeria's depends on the entrepreneurial energy of vibrant SMEs because a lot of large businesses start out as SMEs. Many authors believe that they are the starting point of development in the economy towards industrialization. Udechukwu (2003) for example sees the SME sector as one that will enhance the contributions of the private sector and provide the critical building blocks for industrialization and sustainable economic growth. SMEs broaden the base of participation in society, decentralize economic power and give people a stake in the society's future (Williams, 2006). SMEs have also been recognized as a channel for improving the efficiency of domestic markets and making productive use of scarce resources, and thus facilitating long-term economic growth in poor countries (Aryeetey \& Ahene, 2004). Given that a large proportion of Nigeria's population relies either directly or indirectly on small and medium enterprises for survival, their importance cannot be overemphasized.

A major contribution made by SMEs is in the area of employment as they offer a high amount of employment in casual, part-time, low training, low-skilled jobs (Yaobin, 2007). Being more labor intensive, SME expansion is more likely to boost employment than large enterprises where expansion means higher degree of automation and machining. Findings from a study carried out by Chu, Kara \& Benzing (2008) suggest that Nigerians consider entrepreneurship an avenue leading to job security and improving their livelihood. This makes SMEs an important factor in the area of poverty alleviation (Beck, Demirguc-Kunt \& Levine, 2005).

SMEs are thought to be engine room of innovation and because they enhance competition and entrepreneurship, they have external benefits on economy-wide efficiency, and aggregate productivity growth. They lead to economic dynamism and greater social inclusion in the European Union. (Avolio, n.d, Beck, Demirguc-Kunt \& Levine, 2005; Chu, Kara \& Benzing, 2008). Small and Medium Enterprises serve as links between the large business enterprise and the consumers as such, large enterprises can hardly survive without them.

According to Akinsulire (2010), small and medium scale enterprises accelerate rural development while decreasing urban immigration and the problems of congestion in large cities because they have lesser competition by serving dispersed local markets, are closer to their resources and are cheaper to establish in the urban areas entrepreneurs are attracted to invest thus discouraging rural-urban migration and making for an even development. SMEs also contribute to domestic capital formation, play a value-adding role, mobilize private savings and harness them for productive purposes.

Kilby (1969) as cited in Ekpenyong \& Nyong(1992) sees SMEs as a quasi sponge for urban employment and a provider of inexpensive consumer goods with little or no import content, serving an important pressure-releasing and welfare-augmenting function. SMEs also contribute to long-run industrial growth by producing an increasing number of firms that grow up and out of the small-scale sector. 


\subsection{The Concept of Taxation}

According to Eftekhari (2009), taxation has always been an issue for the government and taxpayers alike from the early years of civilization. The issue of taxation has generated a lot of controversy and severe political conflicts over time. According to its importance, several economic theories have been proposed to run an effective system. Gabay, Remotin \& Uy (n.d) see taxation as the process by which the sovereign, through its law making body, raises revenues used to defray expenses of government, a means of government in increasing its revenue under the authority of the law, purposely used to promote welfare and protection of its citizenry, and the collection of the share of individual and organizational income by a government under the authority of the law. Iwuji (n.d.) defines tax as a statutory compulsory contribution imposed by government exacted from a person's or entity's income, property or transaction for the purpose of funding governance. A tax can either be of three basic structures; proportional, regressive or progressive. Tax is said to be proportional when the taxpayer is levied an amount that is an indirect proportion of his income. A regressive tax is one that charges a higher rate to persons receiving lower income, and finally a progressive tax levies a higher rate to higher income earners.

Nigeria runs a tripartite tax administration system where tax assessment and collection is presently carried out through the revenue collection agencies of the State and Federal Governments of Nigeria: the State Board of Internal Revenue (SBIR) and the Federal Inland Revenue Service (FIRS) and the tax administration in Nigeria is basically imposed through Acts of the National Assembly.

\subsection{Tax Policy and the Growth of SMEs}

According to Tomlin (2008), economists argue that the resources smaller companies direct towards tax compliance are resources that could otherwise be used for reinvestment, facilitating future growth. Hence, there is a belief that taxes and a complex tax system put disproportionate pressure on smaller businesses. Small taxpayers under the regular system of taxation are discriminated against, since the compliance requirements, cost of compliance and tax rate are the same for both small and large enterprises. Reducing the compliance costs and tax rate increases the small enterprises profit margin. It also increases the Government's tax revenue, since the simplified provisions for a micro enterprise historically reduce the size of the shadow economy and the number of non-complying registered taxpayers (Vasak, 2008).

Furthermore, SMEs usually have to operate in an overbearing regulatory environment with the plethora of regulatory agencies, multiple taxes, cumbersome importation procedure and high port charges that constantly exert serious burden on their operations. Many SMEs have to deal with myriad of agencies at great cost. As stated earlier they are heterogeneous and these differences in size and structure may in turn carry differing obligations for record-keeping that affect the costs to the enterprises of complying with (and to the revenue authorities of administering) alternative possible tax obligations. Public corporations, for example, commonly have stronger accounting requirements than do sole proprietorships, and enterprises with employees may be subject to the full panoply of requirements associated with withholding labor income taxes and social contributions (International Tax Dialogue 2007).

In carrying out their responsibilities, tax administrations can also create problems for the business community when they impose burdensome reporting and record keeping requirements; conduct excessive inspections and audits; fail to deal with corrupt tax administration employees; and, fail to provide transparency in tax administration operations. This type of environment harms individual businesses and the overall economy. As a result, many in the business community react by taking steps which adversely affect the tax base. This typically includes underreporting profits and turnover; underreporting employee wages; and, by creating "phantom" employees. A significant number of businesses also fail to register or file tax declarations. This only increases the burden on those taxpayers who try to comply with the tax law, and discourages their future compliance. The result is a vicious cycle which tends to preserve the status quo. Only meaningful reforms to the tax system can break the cycle and result in an improved business climate which will stimulate economic growth. (Baurer, 2005)

An overly complex regulatory system and tax regime or one opaque in its administration and enforcement makes tax compliance unduly burdensome and often have a distortionary effect on the development of SMEs as they tended to morph into forms that offer a lower tax burden or no tax burden at all (Masato, 2009), producing a tax system that imposes high expenses on the society. A poorly executed tax system also leads to low efficiency, high collection charges, waste of time for taxpayers and the staff, and the low amounts of received taxes and the deviation of optimum allocation of resources (Farzbod, 2000). Existing empirical evidence clearly indicates that small and medium sized businesses are affected disproportionately by these costs: when scaled by sales or assets, the compliance costs of SMEs are higher than for large businesses (Weichenrieder, 2007) because of low 
efficiency, high collection charges, waste of time for taxpayers and the staff, and the low amounts of received taxes and the deviation of optimum allocation of resources (Farzbod, 2000; Yaobin, (2007).

\subsection{Policy Measures That Will Encourage Growth of SMEs}

Although some policy measures are geared towards SME growth in Nigeria, the support needs to be increased, standardized and systematic. Iwuji (n.d) believes that it is the role of the government to provide the enabling environment and social services that support businesses and entrepreneurs, and thus enhancing the investment climate in Nigeria for increased economic growth and subsequent tax contribution from all citizens, since a good number of SMEs operate in the informal economy due to the fact that they deem the tax environment within which they operate as unfavorable. These SMEs constitute untapped revenue potential and an uneven playing field in many countries (International Tax Dialogue, 2007) as such they need to be captured by the tax net.

The legislation is a necessary regulator for protection of the business environment and security of the economic agents, for establishment of the necessary social security regulations but at the same time it hampers the business with additional expenditures and administrative obstacles, which place in different positions the SME. The big companies have more choices possibilities. They can either share part of the staff or hire people to deal only with studying the legal requirements and complying with the new regulations, or contract some personal service firm (like E\&Y, Deloitte and Touché, Price Waterhouse etc) to deal with their tax compliance, planning etc. For SME this is a great expense out of their abilities. (Smatrakalev, 2006)

Shahrodi, (2010) believes that for a tax system to be efficient, the tax policy needs to be designed such that the tax rates are appropriate and rational, the exemptions are lower in amount, the tax collection organization are more efficient, the tax burden of the indigent people should be lighter and the fight against corruption and tax evasion should be much more intense.

Tax policies can be designed in such a way that they do not only directly affect SMEs but also indirectly push for their growth for example the practice in China where tax policy has been designed to encourage SME financing by granting exemptions from business tax for financial corporations that provide guarantee for loans to SMEs and granting tax deductions to market entities and venture capitalists that invest in high-tech SMEs the tune of $70 \%$ of the investment value. Another way is by designing tax policies that encourage human capital training. (Yaobin, 2007)

Special tax regimes for SMEs may be appropriate policy instruments for minimizing the cost of collection. It is important to note that the awareness of the dangers of inadequate attention to the taxation of SMEs has grown. It can lead, for example, to distortions of competition as a result of uneven tax enforcement, with incentives created to limit growth and to avoid tax through artificial splitting of enterprises. Not least, voluntary compliance by larger enterprises themselves, and by wage earners, may be undermined by the (correct) perception that their smaller counterparts, or better-off neighbors, are getting away with poorer compliance. (International Tax Dialogue, 2007) Hence government intervention will help maintain balance while helping countries exploit the social benefits from greater competition and entrepreneurship. The European Charter for Small Enterprises for instance, sets the objective that "Tax systems should be adapted to reward success, encourage start-ups, favour small business expansion and job creation, and facilitate the creation and the succession in small enterprises. Member States should apply best practice to taxation and to personal performance incentives."

Arguments are sometimes made for preferential treatment of smaller enterprises on pure policy grounds: if they have difficulty raising external finance, for example, a reduced tax rate on retained earnings, freeing more internal finance, may seem useful. The importance of this and other possible market imperfections in impeding realization of the full potential of SMEs remains unclear. The crucial points, however, are that size itself may not be closely associated with the relevant market failure (some smaller enterprises may face no financial constraints, for example), and tax interventions will often be dominated by targeted spending measures (such as development loans). Inadvertent damage to smaller enterprises from flawed tax design should be avoided, but the case for preferential treatment is far from clear. (International Tax Dialogue, 2007).

Furthermore, policy incentives such as tax rebate for SMEs that put effort on local sourcing of raw materials, serious in adding value to commodities for exports and other business ethics, should be employed by government. Similarly, government could increase funding for the development of the sub-sector through direct budgetary allocations and enhance private sector investment opportunities that will focus on specific areas of capacity enhancement.

The use of tax incentives are encouraged because they are "fiscal measures that are used to attract local or foreign investment capital to certain economic activities or particular areas in a country (SADC Memorandum of 
Understanding on taxation, 2002). They are deliberate reductions in tax liability to compensate for deficiencies in the investment environment and entry of players into the sector (Iwuji, n.d), thus attracting investment and creating a prospective source of tax revenue, encourage savings and stimulate investment that leads to a better economy (Bolnick, 2004).

Tax law should be simplified continuously, mainly for three reasons, namely to lower both compliance costs and administrative costs, to reduce uncertainty faced by taxpayers; and to improve the levels of voluntary compliance (Kasipillai, 2005). Pro-business (and Pro-SME) Tax regimes and enforcement should be simple, consistent and predictable. In Uzbekistan for instance, one of the steps that promoted the development small businesses was the adoption of a simplified system of taxation for micro-firms and small enterprises in 1998. Tadjibaeva \& Komilova (2009) reported that the simplified order of taxation proposed payment of a single tax in lieu of all federal and local taxes and payments (except trade, licensing and registration duties). The rates of single tax vary according to the industry in which the SME operates. The shift to a simplified system of taxation substantially reduced tax burden of small businesses and tax administration procedures became less cumbersome and costly, mainly in bookkeeping and reporting. SMEs were eligible to use either simplified or general accounting procedures based on their preference. Encouraging SMEs to maintain good accounts is also a way to help the SMEs because the associated good record keeping for tax purposes is also beneficial to the businesses' financial health (Iwuji, n.d). Others are continued reduction of tax rates for SMEs, improving the technological development of preferential tax policies which will invariably reduce the compliance costs of SMEs and strengthening the services of tax administration towards SMEs.

\subsection{Theories of Business Growth}

Various authors have postulated theories pertaining to business growth. The oldest and most common theory according to Elhiraika \& Nkurunziza (2006) is Gibrat's 'Law of Proportionate Effect-LPE', (1931). Here, Gibrat stipulates that the rate of growth of a firm is independent of its initial size. By implication, it would mean that large firms are preferable in the context of private sector development given that they create more employment than small firms. Conversely, Jovanovic (1982) states in his 'Learning model' that younger firms learn over time, which helps them improve their performance as they accumulate market knowledge. According to this model, young firms grow faster than old ones. Moreover, given that younger firms are usually smaller than older businesses for the reasons discussed above, Jovanovic deduces that small firms grow faster than large ones. This is a convergence process where small firms will eventually become as large as any other large firm in the same sector over time.

Churchill and Lewis (1983) as cited in Olawale \& Garwe (2010) on the other hand claim that as a new small firm starts and develops, it moves through some growth stages, each with its own distinctive characteristics. These authors also identified the stages of growth as; existence, survival, success, take-off and resource maturity. In each stage of development as different set of factors is critical to the firm's survival and success. The Churchill Lewis model gives an insight into the dynamics of SME growth, including the distinguishing characteristics, problems and requirements of growing SMEs and explains business growth processes amongst SMEs. The precise moment in time in which a start-up venture becomes a new business has not yet been theoretically determined. However, the idea of business survival could be equated with a firm that has fully completed the transaction to stage-two organization in the five stages of small business growth.

\section{Research Methodology}

The research is an explanatory or a causal study. This is because it is a research that it is aimed at establishing causal relationship between two variables i.e. the relationship between tax policy and the growth of SMEs. Since it involves collecting the views, perspectives or opinions of respondents regarding a particular issue or research interest, it employed the survey method using questionnaires, personal interviews with respondents and perusal of past records and publications. This choice was made due to the fact that the survey method is effective when it comes to getting opinions, attitudes and descriptions as well as for getting cause and effect relationships (Ghuari and Gronhaug 2005). The selection of small and medium enterprises was done by judgmental sampling in order to attempt obtaining a fair representation of the population. Samples were collected from 150 SMEs with different ownership and legal structures and at different levels of development by so doing obtaining a fair representation of the population.

The survey method was chosen because authorities have questioned methods involving simply asking people questions either in self administered questionnaires or through interviews (Olu, 2005), while the primary instrument for data collection for the purpose of this study is the questionnaire. The questionnaire consists of properly constructed open and close ended questions that will make it easier to obtain precise answers from the 
respondents. The face validity and content validity of the questionnaire were verified by an expert and it was found that the questionnaire contained questions that not only measured the construct but also covered all important aspects of the construct (Cooper \& Schindler, 2008 and Data Analysis Australia, 2009).

The actual field work involved personally collecting data from the selected Small and Medium Enterprises by visiting them individually and administering questionnaires. A total number of 150 questionnaires were distributed, of this number, 107 were returned and 43 were not. This gave a retrieval rate of $71.33 \%$ which was considered reliable enough to base the research on. The location of study for this research is the northern Nigerian city of Zaria, Kaduna State.

The data collected was analyzed using Microsoft Office Excel 2007 and the Statistical Package for Social Sciences (SPSS). The statistical non-parametric test utilized was Spearman's Rank Correlation to establish the strength of association between the two variables. The Spearman's rank correlation coefficient (p) was calculated as:

$$
\rho=\frac{\sum_{i=1}^{n} R\left(x_{i}\right) R\left(y_{i}\right)-n\left(\frac{n+1}{2}\right)^{2}}{\left(\sum_{i=1}^{n} R\left(x_{i}\right)^{2}-n\left(\frac{n+1}{2}\right)^{2}\right)^{0.5}\left(\sum_{i=1}^{n} R\left(y_{i}\right)^{2}-n\left(\frac{n+1}{2}\right)^{2}\right)^{0.5}}
$$

where $\mathrm{R}(\mathrm{x})$ and $\mathrm{R}(\mathrm{y})$ are the ranks of a pair of variables ( $\mathrm{x}$ and $\mathrm{y}$ ) each containing $\mathrm{n}$ observations.

However, where no tied ranks exist, it was calculated as

$$
\rho=1-\frac{6 \sum d_{i}^{2}}{n\left(n^{2}-1\right)} .
$$

\section{Empirical Results and Significance of Findings}

A total number of 150 questionnaires were administered. As seen from the analysis shown in the table above, $71.33 \%$ of these questionnaires were filled and returned while $28.67 \%$ of the questionnaires were not returned. The rate of retrieval $(71.33 \%)$ is reasonable enough to base a research on and draw valid conclusions from that research.

\section{Hypothesis 1}

$\mathrm{H}_{0}$ : There is no significant relationship between tax and the SMEs' ability to expand

$\mathrm{H}_{1}$ : There is a significant relationship between tax and the SMEs' ability to expand.

Test of Hypothesis 1 using Spearman's Rank Correlation

Table 1. Test of hypothesis 1using spearman's rank correlation

\begin{tabular}{lllrr}
\hline & & & $\begin{array}{c}\text { Estimated } \\
\text { Percentage } \\
\text { Taxes }\end{array}$ & $\begin{array}{r}\text { Project Carried } \\
\text { out of Business } \\
\text { Profit }\end{array}$ \\
\hline Spearman's rho & $\begin{array}{l}\text { Estimated Percentage } \\
\text { Taxes }\end{array}$ & Correlation Coefficient & 1.000 & $-.152\left(^{*}\right)$ \\
& & Sig. (2-tailed) &. & .015 \\
& N & & 91 & 91 \\
& Projects Carried out of & Correlation Coefficient & $-.152\left(^{*}\right)$ & 1.000 \\
& Business Profit & Sig. (2-tailed) & .015 & 157 \\
& $\mathrm{~N}$ & 91 &. \\
& & &
\end{tabular}

* Correlation is significant at the 0.05 level (2-tailed).

Source: Field Survey 2011 
The Spearman's Rank correlation coefficient (Rho) obtained was -0.152 at a two-tailed level of significance of 0.015 , implying that there is a weak negative correlation between the amount of taxes paid and the number of projects carried out of business profits. Hence, the null hypothesis $\left(\mathrm{H}_{0}\right)$ was rejected and the alternative hypothesis $\left(\mathrm{H}_{1}\right)$ accepted.

\subsection{Discussion of Result}

The negative albeit weak correlation between taxes paid and projects carried out of business profits indicates that the lower the amount of taxes paid by the SME, the greater the growth related business project the profits are used for. The weak correlation suggests that there are some other factors apart from tax that also affect SMEs' ability to expand. According to the International Tax Dialogue (ITD, 2007) a reduced tax rate will free more internal finance for SMEs. This supports the assertion of Horsepower (2001) which states that reduced tax rates improve internal financing which in turn enhance internal accumulation. Furthermore, Tadjibaeva \& Komilova (2009) have found that tax rate is one of the factors that affect the prosperity of entrepreneurs. Thus, Low re-investment will eventually lead to a slow rate of business expansion.

\subsection{Empirical Findings}

From analysis of the responses obtained from the questionnaires, the following findings were made:

(i) There is a negative correlation between tax and a small business' ability to expand. By implication, it can be said that the higher the amount paid as tax by SMEs, the lower the amount of funds available for re-investment into the business. Low re-investment will eventually lead to a slow rate of business expansion.

(ii) There is a negative relationship between tax and a small business' ability to sustain itself. This means that the firms paying the lower taxes are able to stay in business for a longer period of time than those that pay lower taxes. Because lower tax rates frees up more funds which can be used as working capital. Hence there is a higher chance of the business living longer.

\section{Conclusion}

From the foregoing, it can be concluded that SMEs play an important role in the growth and development of the Nigerian economy. It can also be concluded that a friendly tax policy is instrumental to the survival and growth of these small and medium enterprises. However, taxes for SMEs have been more harmful than beneficial as they increase running costs and slow down growth. Most of the SMEs surveyed are faced with the problem of high tax rates, multiple taxation, complex tax regulations and lack of proper enlightenment or education about tax related issues. Therefore, if SMEs are to flourish, an appropriate tax policy which will not be an encumbrance to the growth of SMEs needs to be on ground.

\subsection{Recommendations}

Based on the findings made from this research study, the following recommendations are therefore made:

(i) Tax regulations governing SMEs should be simplified in order to make compliance easier for them. This includes clear and simple tax regulations, and an undemanding tax filing process. The use of information technology should be encouraged.

(ii) Tax administrators should carry out their duties more efficiently with the most care and integrity as this will help combat issues such as multiple taxes.

(iii) Tax administrators should improve their support services towards SMEs for example, small business owners should be educated on issues such as taxes they are expected to pay and the incentives and exemptions they are eligible for.

\section{References}

Aderemi, A. (2003, June). Small and medium scale enterprises: The Nigerian situation. [Power Point Slides] Capital Partners Limited. Retrieved from www.capitalpartnersltd.com/Small\%20Medium\%20Scale.ppt

Akinsulire, O. (2010). Financial management. Lagos: Ceemol.

Ariyo, D. (2005). Small firms are the backbone of the Nigerian economy. Retrieved October $22^{\text {nd }}$, 2010, from http://www.africaeconomicanalysis.org/articles/gen/smallhtm.html

Aryeetey, E., \& Ahene, A. (2004). Changing regulatory environment for small-medium size enterprises and their performance in Ghana (CRC Working Paper No. 30594). Centre on Regulation and Competition (CRC). Retrieved from http://ageconsearch.umn.edu/bitstream/30594/1/cr050103.pdf 
Avolio, C. (n.d.). Policies for business in the Mediterranean Countries Slovenia. Retrieved from http:/unpan1.un.org/intradoc/groups/public/documents/caimed/unpan018702.pdf

Baurer, L.I. (2005). Tax administrations and small and medium enterprises (SMEs) in Developing Countries. Retrieved from http://www.ifc.org/ifcext/sme.nsf/AttachmentsByTitle/BEE+SME+Taxation/\$FILE/SME+Taxation+Toolki t.pdf

Beck, T., Demirguc-Kunt, A., \& Levine R. (2005). SMEs, growth, and poverty: cross country evidence. NBER Working Paper 11224, National Bureau of Economic Research. Retrieved from http://www.nber.org/papers/w11224.pdf

Bolnick, B. (2004). Effectiveness and Economic Impact of Tax Incentives in the SADC Region. Nathan Associates Inc. Arlington, Virginia.

Chu, H.M., Kara, O., \& Benzing, C. (2008). An empirical study of Nigerian entrepreneurs: success, motivations, problems, and stress. International Journal of Business Research, 8(2), 102-116.

Cooper, D.R., \& Schindler, P.S. (2008). Business research Methods (10 ${ }^{\text {th }}$ ed.). New York: McGraw Hill.

Edotsu, N.W. (2008) Down the memory lane. The Market Magazine. Retrieved from $\mathrm{http} / /$ themarketmagazine.com/index2.php?option=com_content\&do_pdf=1\&id=13

Ekpenyong, D.B., \& Nyong M.O. (1992). Small and medium-scale enterprises in Nigeria: their characteristics, problems and sources of finance. (Research Paper 16). Retrieved from African Economic Research Consortium. Retrieved from http://idl-bnc.idrc.ca/dspace/bitstream/10625/9982/1/95971.pdf

Elhiraika, A., \& Nkurunziza, J. (2006). Facilitating firm entry, growth and survival with special attention to SMEs. Economic Commission for Africa, Work in progress ATPC NO. 46.

Farzbod, J. (2000). Investigation of the effective factors in the tax efficiency. Unpublished master's thesis, Governmental Management Training Center, Tehran.

Fjeldstad, O., Kolstad, I., \& Nygaard, K. (2006). Bribes, taxes and regulations: Business constrains for micro enterprises in Tanzania. Chr. Michelsen Institute Working Paper. WP 2006:2

Gabay, B.K.G., Remotin, Jr. R.M., \& Uy, E.A.M. (n.d). Economics: its concepts and principles. Retrieved from http://www.slideshare.net/gar_dev/concepts-of-taxation

Ghauri, P., \& Gronhaug, K. (2005). Research methods in business studies: A practical guide (3 ${ }^{\text {rd }}$ ed.). Essex: Pearson Education Limited.

Hanefah, M., Ariff, M., \& Kasipillai, J. (2002). Compliance costs of Small and Medium Enterprises. Journal of Australian Taxation, 4(1), 73-97.

Hendy, P. (2003, August). Threats to Small and Medium sized Enterprises from Tax and other Regulations. Paper presented at the Australian Taxation Studies Program Small Business Tax Symposium, Developing Good Tax Policies for SMEs. Sydney.

Holban, O.I. (2007). The taxation of small and medium-sized enterprises-a hindering factor influencing the european economic growth. Doctoral dissertation, Alexandru Ioan Cuza University of Iasi and Academy of Economies Studies from Bucharest Romania.

Honglang, L., \& Jiaozben, H. (n.d). Research on R\&D financing support for small and medium-sized enterprises. Orient Academic Forum. Retrieved from http://www.seiofbluemountain.com/upload/product/201009/2010cwjrhy04a1.pdf

Ihua, B. G. (2009). SMEs key failure-factors: a comparison between the United Kingdom and Nigeria. Journal of Social Science, 18(3), 199-207.

International Tax Dialogue. (2007). Taxation of Small and Medium Enterprises, Background paper for the International Tax Dialogue Conference, Bueons Aires.

Iwuji, G.I. (n.d) Creating awareness on tax matters for small and medium units. [PowerPoint Slides]. Retrieved

from http://www.docstoc.com/docs/19747636/Creating-Small-and-Medium-Enterprises-Tax-Matters-Awareness.

Kasipillai, J. (2005). A Comprehensive Guide to Malaysian Taxation: Current Year Assessment. Kuala Lumpur: McGraw-Hill. 
Masato, A. (2009). Globalization of Production and the Competitiveness of Small and Medium-sized Enterprises in Asia and the Pacific: Trends and Prospects. Publication of United Nations Economic and Social Commission for Asia and the Pacific (ESCAP), Studies in Trade and Investment Series chapter 1, 1-31.

Oboh G.A.T. (2002). Bank Participation in the Promotion of Small and Medium-Scale Enterprises. Being a paper presented at the 6th Fellows and Associates Forum of CIBN on 13th April.

Okpara FO. (2000). Entrepreneurship (Text and Cases). Enugu Nigeria: Precision.

Olawale, F., \& Garwe, D. (2010). Obstacles to the growth of new SMEs in South Africa: a principal component analysis approach. African Journal of Business Management, 4(5), 729-738.

Olorunshola, J.A. (2003). Problems and prospects of small and medium scale industries in Nigeria. Paper presented at the Central Bank of Nigeria seminar on small and medium industries equity investment scheme (SMIEIS). Retrieved from www.cenbank.org/out/Publications/guidelines/dfd/2004/smieis.pdf

Olotu, B. (2011, January 22). How to qualify for SME finance. Weekly Trust, pp, 56.

Olu, O. (2005). Fundamentals of research methods. Lagos: Standard Publications.

Panitchpakdi, S. (2006). Statements at the $10^{\text {th }}$ Session of the Commission on Enterprise, Business Facilitation and Development, Geneva, 21 February 2006. Retrieved from http://www.unctad.org/templates/webflyer.asp?docid=6825\&intItemID=4843\&lang=1

Shahrodi, S.M.M. (2010). Investigation of the effective factors in the efficiency of tax system. Journal of Accounting and Taxation, 2(3), 42-45.

Smatrakalev, G. (2006). Tax policy for small and medium enterprises. Paper deliverd at the $6^{\mathrm{TH}}$ Global conference on business and economics. Gut man conference center, U.S.A.

Stern, R.E., \& Barbour P.A. (2005). Designing a small business tax system that enhances growth: lessons from Africa. Retrieved from http://www.fias.net/ifcext/fias.nsf/AttachmentsByTitle/Zambiataxconference_PapersRichardandPaul/\$FILE /Taxing+SMEs+in+Africa_Richard+Stern+and+Paul+Barbour.pdf

Tadjibaeva, D., \& Komilova, I. (2009). The influence of tax reforms on the prosperity of micro-firms and small businesses in Uzbekistan. Asia-Pacific Development Journal, 6(2), 31-64.

Talbabs and associates. (2010). General taxes and enactment. Retrieved October 29, 2010 from http://www.talbabsandassociate.com/history.html

Tomlin, B. (2008). Clearing hurdles: key reforms to make small businesses more successful. (Commentary No. 264). Toronto, Ontario C.D. Howe Institute. Retrieved from www.cdhowe.org/pdf/commentary_264.pdf

Udechukwu, F.N. (2003). Survey of small and medium scale industries and their potentials in Nigeria. Paper presented at the Central Bank of Nigeria seminar on small and medium industries equity investment scheme (SMIEIS). Retrieved from www.cenbank.org/out/Publications/guidelines/dfd/2004/smieis.pdf

Uzor, O.O. (2004). Small and medium scale enterprises cluster development in South-Eastern region of Nigeria. Institute for world Economics and International Management Paper No. 86

Vasak, S. (2008). Small, medium, and large enterprises. USAID Business Climate Reform. Retrieved from http://pdf.usaid.gov/pdf_docs/PNADQ675.pdf

Weichenrieder, A.J. (2007). Survey on the taxation of small and medium-sized enterprises: draft report on responses to the questionnaire. Organization for Economic Co-operation and Development web site. Retrieved from http://www.oecd.org/dataoecd/52/25/39597756.pdf

Williams, E.S. (2006). Supporting the growth of small and medium enterprises. Central Bank of Trinidad and Tobago.

Yaobin, S. (2007, October). Tax, small business, growth: effect of taxation on investment and cross-border trade. Paper presented at the ITD Conference on Taxation of SMEs. 